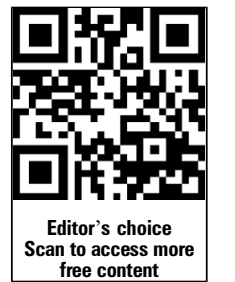

free content
Correspondence to Dr Julian C Sheather, Ethics Department, British Medical Association, London WC1H 9JP, UK: jsheather@bma.org.uk

Received 12 March 2012 Accepted 20 March 2012 Published Online First 17 May 2012

\section{SLinked}

- http://dx.doi.org/10.1136/ medethics-2012-100663

- http://dx.doi.org/10.1136/ medethics-2012-100856

- http://dx.doi.org/10.1136/ medethics-2012-100882

- http://dx.doi.org/10.1136/ medethics-2012-100907

- http://dx.doi.org/10.1136/ medethics-2012-100954

To cite: Sheather JC. J Med Ethics 2013;39:543-546.

\title{
Withdrawing and withholding artificial nutrition and hydration from patients in a minimally conscious state: Re: $M$ and its repercussions
}

\author{
Julian C Sheather
}

\begin{abstract}
In 2011 the English Court of Protection ruled that it would be unlawful to withdraw artificial nutrition and hydration from a woman, $\mathrm{M}$, who had been in a minimally conscious state for 8 years. It was reported as the first English legal case concerning withdrawal of artificial nutrition and hydration from a patient in a minimally conscious state who was otherwise stable. In the absence of a valid and applicable advance decision refusing treatment, of other life-limiting pathology or excessively burdensome suffering, the judgement makes it clear that the obligation on health professionals falls strongly in favour of preserving life. Although the Court sought to limit the judgement as closely as possible to the facts of the case, it is likely to have a significant impact on life-sustaining treatment decisions for people in states of low awareness. This paper outlines the main legal features of the judgement.
\end{abstract}

In the summer of 2011 the English Court of Protection ruled that it would be unlawful to withdraw artificial nutrition and hydration (ANH) from a woman, $\mathrm{M}$, who had been in a minimally conscious state (MCS) for 8 years. ${ }^{1}$ It was reported as the first English legal case concerning withdrawal of ANH from a patient in a MCS and who was otherwise stable. The judgement reiterated the requirement for court review of all decisions relating to withdrawing and withholding ANH from patients in both a vegetative state (VS) and in MCS. In the absence of a valid and applicable advance decision refusing treatment, of other life-limiting pathology or excessively burdensome suffering, the judgement makes it clear that the obligation on health professionals falls strongly in favour of preserving life. ${ }^{2}$ Although the Court sought to limit the judgement as closely as possible to the facts of the case, it is likely to have a significant impact on life-sustaining treatment decisions for people in states of low awareness. In this paper I outline the main legal features of the judgement.

\section{BACKGROUND TO THE CASE}

In February 2003, 'M', then aged 43, was found by her partner in a drowsy and confused condition. She was taken to hospital where she fell into a coma. She had suffered viral encephalitis which had left her with extensive and irreparable brain damage. She has subsequently been entirely dependent on others for her care and fed via a gastrostomy tube. After emerging from coma she was diagnosed as being in a VS. After several years of exploring treatment options her family decided, with the support of the treating doctors, to apply for a court order to withdraw ANH. In the course of subsequent investigations it was discovered that $\mathrm{M}$ was not in a VS but in MCS. The family decided to proceed with the court application. Although M's family reported her as having many times stated that she would not have wanted to remain alive in a completely dependent condition, she had made no formal advance decision refusing treatment, nor had she appointed a health and welfare attorney with the power to make the decision on her behalf.

\section{'BEST INTERESTS' AND 'SUBSTITUTED JUDGEMENT'}

Prior to the coming into force of the Mental Capacity Act 2005 (MCA), common law in England distinguished between welfare decisions and decisions relating to property and affairs. In relation to property, the Courts ordinarily employed a 'substituted judgement' test: they tried to put themselves in the position of the incapacitated adult in order to decide what he or she would have wanted. In the absence of any indication of prior wishes the Court would also assume that he or she was a 'normal decent person' and make decisions accordingly. ${ }^{3}$ In relation to welfare decisions, however, the Courts largely adopted a 'best interests' test which involved the development of a 'balance sheet' approach where the relevant benefits and burdens of the decision could be weighed against each other. ${ }^{4}$ Although a substituted judgement test can encounter difficulties where, for example, the individual in question had not been able to indicate views, wishes or feelings, it is in general more respectful of the prior autonomy of adults who have been capable of self-directing choices. In the USA a substituted judgement approach is far more widely used, including in relation to health and welfare decisions. In contrast, a best interests judgement, although capable of being weighted to incorporate former wishes, tends to give equal or greater emphasis to the incapacitated individual's current welfare.

\section{THE MENTAL CAPACITY ACT AND 'BEST INTERESTS'}

In England and Wales, decisions relating to adults who lack the capacity to make decisions on their own behalf are made under the MCA. The MCA 
states that 'an act done, or decision made, under this Act for or on behalf of a person who lacks capacity must be done, or made, in his best interests'. The Act does not provide a definition of best interests. Instead it lays out a number of factors that must be taken into consideration when determining what would be in the adult's best interests. These include:

- The person's past and present wishes and feeling-and in particular any written statement written when he had capacity.

- The person's beliefs and values.

- The views of anyone named by the person as someone to be consulted.

- The views of anyone engaged in caring for the person. ${ }^{5}$

Where known, an individual's prior wishes will therefore be relevant to any best interests judgement-a best interests judgement incorporates aspects of substituted judgement although, as in the case of $\mathrm{M}$, in the absence of sufficiently documented proof, those earlier wishes may not be determinative. What the Act therefore does, in a case like M's, is invite the decisionmaker to balance more general prior wishes and feelings- to give some respect to the individual's precedent autonomyagainst more 'objective' contemporaneous welfare interests.

\section{THE MCA AND LIFE-SUSTAINING TREATMENT}

The MCA explicitly distinguishes decisions relating to lifesustaining treatment, subjecting them to restrictions in relation to the intentionality of the decision-maker. The Act states:

Where the determination relates to life-sustaining treatment he must not, in considering whether the treatment is in the best interests of the person concerned, be motivated by a desire to bring about his death. ${ }^{6}$

In its judgement in $\mathrm{M}$ the Court also makes reference to guidance in the MCA Code of Practice relating to best interests decisions involving life-sustaining treatment. The Code states:

\begin{abstract}
All reasonable steps which are in the person's best interests should be taken to prolong their life. There will be a limited number of cases where treatment is futile, overly burdensome to the patient or where there is no prospect of recovery. In circumstances such as these, it may be that an assessment of best interests leads to the conclusion that it would be in the best interests of the patient to withdraw or withhold life-sustaining treatment, even if this may result in the patient's death. The decision-maker must make a decision based upon the best interests of the person who lacks capacity. ${ }^{7}$
\end{abstract}

\section{SUPPORTING CASE LAW}

Although the MCA sets out the legal framework for making decisions on behalf of adults lacking capacity, the Court sought guidance in relation to $M$ from precedent, in particular from Lord Goff's speech in Bland. For those unfamiliar with that case, Anthony Bland suffered catastrophic brain damage after being crushed at the Hillsborough football stadium disaster. Diagnosed as being in a VS, the Court, in a landmark judgement, held that it would be lawful to withdraw medical treatment including ANH even though it would inevitably result in death. ${ }^{8}$ In relation to $\mathrm{M}$, the Court drew the following principles from Bland:

- The principle of sanctity of life is fundamental.

- That principle is not absolute and may yield in certain circumstances.

- A decision about withdrawing ANH must be determined by what is in the best interests of the patient.
- In the great majority of cases the best interests of the patient will require that treatment should be given.

- In some cases the decision whether to withhold treatment would be made by weighing up relevant and competing considerations.

- In Bland such an approach was inappropriate as the treatment in question was 'futile'.

Reviewing case law subsequent to Bland, the Court elicited the following additional points:

- The burden of establishing that discontinuance of treatment is in a person's best interests is always on those who assert that life-sustaining treatment be withdrawn. ${ }^{9}$

- In cases of doubt, that doubt falls to be resolved in favour of the preservation of life. ${ }^{9}$

The very strong presumption therefore is that, given a reasonable chance of achieving its therapeutic goal, life-sustaining treatment should be given, and that this is an expression of the fundamental principle of the 'sanctity of life'. There are, however, exceptional circumstances where, for example, a patient such as Anthony Bland is in PVS, in which that principle can be set to one side. In other circumstances, the strength of the principle is mediated by an assessment of the balance of interests and burdens in the particular case-hence the 'balance sheet' approach.

\section{ASSESSING M'S BEST INTERESTS}

Having identified the legal obligation to make the decision regarding $\mathrm{M}$ on the basis of her best interests, a substantial part of the judgement is necessarily given over to their assessment. As any decision to withdraw ANH from a patient in MCS must be referred to the Courts, and as the Court has now given clear directions as to how MCS should be clinically diagnosed, we lay out in some detail the factors that the Court took into consideration.

\section{The diagnosis of MCS}

In making a best interests judgement, the Court drew a distinction between $\mathrm{M}$ and patients such as Tony Bland in PVS:

She is sensate, clinically stable, aware of herself and her environment, able to respond to people and to music and also, in a very limited way, to communicate about her needs. In short, she is recognisably alive in a way that a patient in VS is not. ${ }^{10}$

Setting to one side the morally critical issue of what is meant here by 'recognisably alive', the distinction between MCS and VS is therefore central in these cases to any assessment of best interests. The Court heard evidence from experts who used two formal clinical assessment tools to assess M's levels of awareness, the Sensory, Modality Assessment and Rehabilitation Technique $^{11}$ and the Wessex Head Injury Matrix. ${ }^{11}$ It held that ' $\mathrm{M}$ is not on the border between VS and MCS, but rather at a moderate level on the MCS spectrum'. ${ }^{12}$

\section{The views of relatives and carers}

In accordance with the requirements of the MCA, ${ }^{13}$ the Court heard a great deal of evidence from those involved in caring for $\mathrm{M}$, including physiotherapists, care workers and nurses. Their testimony runs to some 10 pages of the final judgement and amounts to a lengthy and considered assessment of M's contemporaneous state or states of awareness as well as an assessment of the fluctuating balance of pleasures and pains in her life. Combined with the expert assessments using the tools outlined above and reinforced by the principle of respect for the sanctity 
of life, the evidence relating to M's contemporaneous experiences was largely determinative in this case.

\section{M's wishes and feelings}

As discussed above, the MCA makes it clear that, when assessing whether a decision is in the best interests of an individual, his or her prior wishes will be material. In the absence of a binding advance decision, Counsel acting on behalf of $\mathrm{M}$ argued that the decisive factor in this case should nevertheless still be M's previous wishes and feelings and not the principle of the sanctity of life. M's family were strongly of the view that she would have rejected her current treatment, in particular they cited her views that someone in the condition of Anthony Bland should be allowed to die. In moving testimony, M's sister, for example, asks:

What can she possibly get out of life? No pleasure. The daily routine of being got out of bed, put back, dressed, doubly incontinent. It's not a life, it's an existence and I know she wouldn't want it. ${ }^{14}$

Counsel argued that, 'according true respect to M's autonomy requires the Court to consider seriously what M's view would have been, even if it cannot be conclusively determined, and to give it substantial weight'. ${ }^{15}$ Although the more specific the statement of prior wishes the more weight it would carry, Counsel argued that it did not necessarily follow that more general statements should be set aside. Interestingly as well, Counsel for $\mathrm{M}$ addressed the critical question of whether M's current wishes and feelings might be different from her wishes and feelings when she had capacity. Now that she was in a MCS, her wishes may be very different from those informally expressed before the encephalitis. Counsel held, however, that because her disability is so extreme and that 'her world has shrunk so much; her interests (from her perspective) are now so marginal; and her present self is so fundamentally incapable of sustained or consistent autonomous thought and direction even on the most basic level', ${ }^{15}$ her previous wishes should obtain. Her contemporaneous interests, according to her Counsel, are too slight to be preferred to the interests she expressed prior to her illness.

This then was the critical disagreement between the parties. In the absence of a formal advance decision refusing the specified treatment, what weight should be given to an individual's informally expressed earlier wishes, bearing in mind that the law clearly states that they need to be taken into account, and what weight should be given to her experiential interests at a time when she is no longer capable of expressing, or even perhaps of understanding and fashioning, her own interests? In the Court's view, in this instance, in the absence of clearly documented evidence that her previous statements amounted to a clearly thought-through statement of intent, a respect for M's prior autonomy interests should not be determinative and the emphasis should be on her current welfare. Given the importance attached to the sanctity of life and the fatal consequences of withdrawing ANH, 'it would be ... wrong to attach significant weight to ... statements made prior to her collapse'. ${ }^{16}$

\section{Dignity}

Although not specifically identified as an issue by the MCA, Counsel for $M$ made reference to the lack of dignity attendant on M's condition and argued that M's dignity would be promoted by the withdrawal of ANH rather than its continuance. Frequently raised in relation to end-of-life treatment, the concept of dignity can be elusive. Although arguably related to the non-instrumental value of human life, to respect for human life's intrinsic value, ${ }^{17}$ it can lend itself, as in this case, to arguments both in favour of continuing life and to its cessation. In this case the Court rejected Counsel's opinion, arguing that there was 'dignity in the life of a disabled person who is being well cared for and being kept as comfortable and as free from pain as possible'. ${ }^{18}$

\section{The balance of pleasure and pain}

Having addressed the question of M's previous and contemporaneous interests, the Court went on to look at the balance of pain and enjoyment in her current experience. Citing expert evidence, it concluded that ' $M$ is regularly in pain ... but not in constant pain, nor does the evidence suggest she is in extreme pain. Nevertheless, the fact that she is in regular pain, and discomfort and distress, is a factor which must be taken in account when conducting the balancing exercise'. ${ }^{19}$ Interestingly, on the side of enjoyment, the Judge set to one side expert opinion that suggested her enjoyment of life was at best neutral and argued that 'comfort and contentment can be ... profoundly positive sensations'. ${ }^{20}$ The pleasures of life of the disabled, he also argued, though at times 'smaller', should not thereby be discounted.

\section{THE CONCLUDING JUDGEMENT}

As indicated above, the Court accepted the veracity of the statements of M's family and friends that, prior to being in a MCS, she had made statements that indicated that she would not have wanted to be kept alive in a state similar to Tony Bland. However, it did not regard her views as directly applicable to withdrawing $\mathrm{ANH}$ in a MCS and therefore did not give them decisive weight. As her life did contain some positive pleasures, and there was every possibility that these could be increased by enhanced care, in the Court's view the sanctity of life was the determining factor and it would not be in M's best interests for ANH to be withdrawn. With regard to future care, the Court made a declaration that the current 'Do Not Attempt Resuscitation' order should continue. It distinguished this from the decision regarding $\mathrm{ANH}$ because of the likelihood, even if CPR were successful, of her brain suffering further damage from hypoxia. With regard to decisions relating to other treatments such as antibiotics, these should be left to the treating clinicians in relation to the specific conditions as they arise.

\section{OBSERVATIONS FOR FUTURE CASES}

In its concluding observations, the Court made the following recommendations for future cases:

- In accordance with paragraph 5 of Court of Protection Practice Direction 9E, all applications to withhold or withdraw ANH from a patient in a VS or MCS must be made to a High Court judge. (The judgement does not indicate, however, whether this is also the case where an attorney has been appointed with the authority to make the decision.)

- No application for an order authorising the withdrawal of ANH from a patient in VS or MCS should be made unless (1) a Sensory, Modality Assessment and Rehabilitation Technique assessment (or similarly validated equivalent) has been carried out to provide a diagnosis of the patient's disorder of consciousness and (2) in the case of a patient thereby diagnosed as being in a MCS, a series of Wessex Head Injury Matrix assessments have been carried out over time with a view to tracking the patient's progress. 


\section{Withdrawing and withholding artificial nutrition and hydration}

Acknowledgements I would like to thank my colleague Veronica English for her thoughts on the manuscript.

\section{Competing interests None.}

Provenance and peer review Not commissioned; internally peer reviewed.

\section{REFERENCES}

W v. M EWHC 2443 (Fam). 2011.

W v. M EWHC 2443 (Fam). 2011. Para 249.

Re: C. 1 FLR 51. 1992.

Re A (Male Sterilisation). 1 FLR 549. 2000.

Mental Capacity Act. 2005. s4(6).

Mental Capacity Act. 2005. s4(5).

7 Department for Constitutional Affairs. Mental Capacity Act 2005 Code of Practice. London: TSO, 2007:para 5.31.
8 Airedale NHS Trust v Bland. All Engl Law Rep. 1993;1:821-96.

9 W v. M EWHC 2443 (Fam). 2011. Para 73.

10 W v. M EWHC 2443 (Fam). 2011. Para 102, para 221.

11 Coma Science Group. Consciousness Scales Employed in the Chronic Setting. http:ll www.coma.ulg.ac.be/medical/chronic.html (accessed 24 Nov 2011).

12 W v. M EWHC 2443 (Fam). 2011. Para 238.

13 Mental Capacity Act. 2005. s4(7) (a)-(d).

14 W v. M EWHC 2443 (Fam). 2011. Para 112.

15 W v. M EWHC 2443 (Fam). 2011. Para 225.

16 W v. M EWHC 2443 (Fam). 2011. Para 230.

17 Dworkin R. Life's Dominion: an argument about abortion, euthanasia and individual freedom. London: Harper Collins, 1995:236.

18 W v. M EWHC 2443 (Fam). 2011. Para 241.

19 W v. M EWHC 2443 (Fam). 2011. Para 233.

20 W v. M EWHC 2443 (Fam). 2011. Para 235. 